\title{
Effect of light conditions and ABA on cold storage and post- storage propagation of Taraxacum pieninicum
}

\author{
Monika Kamińska $^{1}$ - Edyta Skrzypek ${ }^{2}$ Emilia Wilmowicz ${ }^{1} \cdot$ Andrzej Tretyn $^{1}$ • \\ Alina Trejgell ${ }^{1}$
}

Received: 12 February 2016/Accepted: 21 June 2016/Published online: 27 June 2016

(c) The Author(s) 2016. This article is published with open access at Springerlink.com

\begin{abstract}
Taraxacum pieninicum is an extremely threatened species. It seems that traditional protection methods of this species are insufficient and it is necessary to use biotechnology tools that allow the in vitro storage of plant material. The present study describes in vitro conservation of T. pieninicum by slow-growth storage. Various light conditions and abscisic acid (ABA) treatments and combinations thereof were tested. Viability, proliferation rate and ability of shoots to root were evaluated during regrowth. Moreover, the effect of shoot storage conditions on the ABA level was analysed. The results showed that light during 3-months' storage increased the level of endogenous ABA. Similar results were observed when storage at a low temperature was prolonged to 9 months. Changes in ABA level had a negative effect on shoot condition. However, these changes were related to leaves and did not affect the ability of shoot tips to proliferate after long-term storage. Addition of $\mathrm{ABA}$ to storage medium increased several folds the level of $A B A$ in plant tissues, which resulted in a reduction in the visual rating and proliferation rate. Shoots obtained after post-storage regrowth were able to root. All rooted shoots survived adaptation to field conditions and were able to flower in the second year after acclimatization. The analysis of DNA content indicated that all the regenerants had the same ploidy level independent of treatments during storage. Cold storage of $T$. pieninicum as used in this study enabled the interval between subcultures to be extended to 9 months.
\end{abstract}

Alina Trejgell

trejgell@umk.pl

1 Chair of Plant Physiology and Biotechnology, Nicolaus Copernicus University, Lwowska 1, 87-100 Toruń, Poland

2 The F. Górski Institute of Plant Physiology, Polish Academy of Sciences, Niezapominajek 21, 30-239 Kraków, Poland
Keywords ABA $\cdot$ Flow cytometry $\cdot$ Light $\cdot$ Slow-growth storage $\cdot$ Taraxacum pieninicum

\section{Introduction}

Taraxacum pieninicum Pawł. (Asteraceae) is probably the oldest endemite of the Pieniny Mountains (Poland). The present population of $T$. pieninicum consists of two clusters of a small number of individuals. This species is listed as critically endangered (CR), and even as declining-critically endangered (E) on Polish red lists (Zarzycki and Szeląg 2006; Wróbel and Zarzycki 2008). Protection of $T$. pieninicum involves constant monitoring of its natural habitat as well as protection of the gene pool in the Seed Bank of the Polish Academy of Sciences (PAS) Botanical Garden-Center for Biological Diversity Conservation (CBDC) in Powsin, Warsaw. However, the availability of seeds is very limited. Additionally, a protocol for in vitro micropropagation of $T$. pieninicum has been developed (Trejgell et al. 2013). However, plant propagation through tissue culture requires transfer to fresh medium every 3 weeks, thus the procedure is laborious, costly and fraught with the risk of somaclonal variation and microbiological contamination. Therefore, it seems to be reasonable to develop a method of cultivating $T$. pieninicum at minimal growth conditions, which will lead to an increase in the intervals between subcultures and reduce the risk of changes in the genetic material.

\section{Slow growth}

In vitro techniques used to achieve short- or medium-term conservation allow the storage of plant material from several months to a few years without subculture, 
depending on the technique used and on the plant material (Cruz-Cruz et al. 2013).

Slow growth is usually achieved by modifying the environmental and/or culture medium. A widely used technique is the reduction of temperature, which can be combined with a decrease in light intensity or by keeping cultures in complete darkness (Engelmann 2011). Storage temperature is closely related to the origin of plants: temperate species may be stored at $4{ }^{\circ} \mathrm{C}$, whereas tropical plants require temperatures in the range of $15-20{ }^{\circ} \mathrm{C}$, which is associated with their sensitivity to reduced temperatures. Slow growth can also be achieved by lowering the oxygen concentration by covering explants with a layer of liquid medium or mineral oil, or by placing them in a controlled atmosphere (Paunescu 2009). Another technique involves modification of the medium including a reduction in mineral and sugar concentration, changes in the concentration of growth regulators and/or addition of osmotic agents and growth retardants (Engelmann 2011). Growth retardants are natural or synthetic chemical substances that can be directly applied on plants to change structural or vital processes by modifying hormone balance. Growth retardants act as chemical signallers in the regulation of plant growth and development. They usually bind to receivers in the plant and initiate a series of cell changes that can affect the initiation or modification of organ or tissue development (Espindula et al. 2009). Growth retardants include abscisic acid, maleic hydrazide, N-dimethylaminosuccinamic acid, phosphon D and acetylsalicylic acid (Gopal et al. 2002).

The objective of this study was to (1) develop a protocol for in vitro shoot tips storage of Taraxacum pieninicum and (2) to analyse the impact of light conditions and ABA during storage on post-storage regrowth.

\section{Materials and methods}

\section{Plant material and culture conditions}

The seeds came from the collection of the Polish Academy of Sciences Botanical Garden-Center for Biological Diversity Conservation in Powsin (Poland). They were surface-disinfected with $70 \%$ (v/v) ethanol for $30 \mathrm{~s}$ and then $20 \%(\mathrm{v} / \mathrm{v})$ commercial bleach $\left(\right.$ Domestos $\left.^{\circledR}\right)$ for $20 \mathrm{~min}$. Then they were washed 4 times with sterile distilled water. Shoot tips were isolated from a few-day-old sterile seedlings and were cultivated on MS (Murashige and Skoog 1962) medium supplemented with $3 \%$ sucrose, $0.8 \%$ agar and $1.1 \mu \mathrm{M}$ BAP and $0.14 \mu \mathrm{M}$ NAA. The $\mathrm{pH}$ of the medium was adjusted to 5.8 before autoclaving. The explants were cultivated in $100 \mathrm{ml}$ Erlenmeyer flasks containing $30 \mathrm{ml}$ proliferation medium for 4 weeks under continuous white fluorescent light $\left(80 \mu \mathrm{mol} \mathrm{m}{ }^{-2} \mathrm{~s}^{-1}\right)$ at $26 \pm 1{ }^{\circ} \mathrm{C}$ (optimal growth conditions). The material to storage was isolated from individual shoots, which were excised from obtained shoot clusters.

\section{Storage conditions}

The shoot tips were deposited in polycarbonate Magenta ${ }^{\circledR}$ boxes with a polypropylene cover that contained $50 \mathrm{ml}$ half-strength MS nutrient medium (1/2MS) supplemented with $3 \%$ sucrose, $0.8 \%$ agar and with or without $5 \mu \mathrm{M}$ ABA. Non-stored shoot tips were used as control. The experiment was conducted in darkness or in continuous white fluorescent light $\left(40 \mu \mathrm{mol} \mathrm{m}{ }^{-2} \mathrm{~s}^{-1}\right)$ at $10{ }^{\circ} \mathrm{C}$ for 3,6 or 9 months.

\section{Data collection}

The microshoots were evaluated at 3 month intervals. Analysis of viability and the visual rating of stored shoots were evaluated directly after transfer to optimal growth conditions. Shoots were rated on the scale from 0 to 5 , on the basis of plant appearance (modified scale, Reed 1992): 0-dead shoot, all brown, 1-shoot mostly brown, only extreme shoot tips visibly yellow, 2-shoot yellow-brown, 3-shoot with etiolated tips, base of stem brown, 4-shoot with etiolation, 5-shoot bright green. Some of the stored shoots were analysed in terms of endogenous ABA content, while the rest of the shoots were subcultured twice on MS medium with full-strength nutrients supplemented with $3 \%$ sucrose, $1.11 \mu \mathrm{M}$ BAP, $0.14 \mu \mathrm{M}$ NAA and $0.8 \%$ agar under continuous white fluorescent light $\left(80 \mu \mathrm{mol} \mathrm{m} \mathrm{m}^{-2}\right.$ $\mathrm{s}^{-1}$ ) at $26 \pm 1{ }^{\circ} \mathrm{C}$. The proliferation rate was evaluated after each 4-week subculture. The obtained shoots were transferred onto rooting medium (MS without plant hormones). The percentage of rooted shoots and the number of roots per shoot were recorded after 4 weeks of culture. The plantlets were removed from the Magenta ${ }^{\circledR}$ boxes, washed gently with sterile water, transferred to plastic pots containing a sterile mixture of vermiculite and sand (1:1 v/v), and covered with transparent boxes to maintain humidity (60-70\%). After 8 weeks of acclimatization survival rates were noted, and then the plantlets were transferred to field conditions. The survival level, the ability to flower and relative nuclear DNA content were analysed in second year after acclimatization.

\section{Measurement of endogenous ABA}

Axillary shoots of T. pieninicum ( $2 \mathrm{~g}$ ) were frozen in liquid $\mathrm{N}_{2}$ and homogenized in a chilled mortar with a pestle. Free ABA was extracted with $80 \%$ methanol (v/v) in two parts of $15 \mathrm{~cm}^{3}$ each. $\left[6-{ }^{2} \mathrm{H}_{3}\right] \mathrm{ABA}(100 \mathrm{ng})$ was added to the 
extract as an internal standard. The extract was reduced to the aqueous phase, acidified to $\mathrm{pH} 2.0$ with $12 \mathrm{M} \mathrm{HCl}$ and centrifuged at $10,000 \mathrm{~g}$ for $30 \mathrm{~min}$ to remove chlorophyll. The supernatant was partitioned three times against ethyl acetate, and dried under vacuum. The pellet was dissolved in formic acid buffer ( $\mathrm{pH} 7-8$ ) and applied to a DOWEX 50 ion exchange column. The column was washed in $\mathrm{H}_{2} \mathrm{O}$ until $\mathrm{pH}$ 7.0. Samples were eluted two times with $2 \mathrm{~cm}^{3}$ of solution containing $0.2 \mathrm{M}$ formic acid and $50 \%$ methanol $(\mathrm{v} / \mathrm{v})$. The eluate was evaporated and further purified by HPLC using a SUPELCOSIL ABZ + PLUS column $(250 \times 4.5 \mathrm{~mm}, 5 \mu \mathrm{m}$ particle size; Supelco Inc., USA). The samples were dissolved in $0.2 \mathrm{~cm}^{3}$ of $20 \%$ methanol $(\mathrm{v} / \mathrm{v})$ and chromatographed with a linear gradient of $20-80 \%$ methanol in $1 \%$ formic acid ( $/ / v)$ in $20 \mathrm{~min}$, flow rate $1.0 \mathrm{~cm}^{3} / \mathrm{min}$ at temperature $22^{\circ} \mathrm{C}$. The fractions collected at $12.57 \pm 0.5 \mathrm{~min}$ were evaporated to dryness, methylated with diazomethane, dissolved in $0.1 \mathrm{~cm}^{3}$ of methanol and analysed by GC-MS-SIM (Auto-System XL coupled to a Turbo Mass, Perkin-Elmer, USA) using a MDN-5 column $(30 \mathrm{~m} \times 0.25 \mathrm{~mm}, 0.25 \mu \mathrm{m}$ phase thickness, Supelco Inc., USA). The GC temperature programme was $120^{\circ} \mathrm{C}$ for $1 \mathrm{~min}, 120-250^{\circ} \mathrm{C}$ at $10^{\circ} \mathrm{C} / \mathrm{min}$, flow rate $1.5 \mathrm{~cm}^{3} / \mathrm{min}$, injection port was $280{ }^{\circ} \mathrm{C}$, electron potential $70 \mathrm{eV}$. The retention times of ABA and $\left[6-{ }^{2} \mathrm{H}_{3}\right] \mathrm{ABA}$ were 14.07 and $14.3 \mathrm{~min}$, respectively. GC-MS-SIM was performed by monitoring m/z 162 and 190 for endogenous $\mathrm{ABA}$ and 166 and 194 for $\left[6-{ }^{2} \mathrm{H}_{3}\right] \mathrm{ABA}$ according to the method described by Vine et al. (1987).

\section{Measurement of relative nuclear DNA content}

DNA content of plantlets after a year of acclimatization to field conditions was evaluated using flow cytometry. Approximately $10-15 \mathrm{mg}$ of young leaves from 3 independent plants of each variant was placed in a $60 \mathrm{~mm}$ glass Petri dish. Lysis buffer $\left(45 \mathrm{mM} \mathrm{MgCl}_{2}, 30 \mathrm{mM}\right.$ sodium citrate, $20 \mathrm{mM}$ 4-morpholinepropane sulphonic acidMOPS, $0.1 \%$ Triton X-100 in distilled water, $\mathrm{pH} 7.0$ ) (Galbraith et al. 1983) was added to the plant material. The tissue was chopped with a razor blade to release nuclei. Individual samples were then filtered to remove debris with a pre-separation filter $30 \mu \mathrm{m}$ nylon mesh (Miltenyi Biotec $\mathrm{GmbH}$, Germany) into $5 \mathrm{ml}$ tubes. The nuclei suspension $(1.5 \mathrm{ml})$ was stained with $30 \mu \mathrm{l}$ of a $2 \%$ propidium iodide (PI) solution. Each sample was gently mixed and incubated for $10 \mathrm{~min}$ at room temperature. Aliquots $(50 \mu \mathrm{l})$ of stained nuclei were mixed and ploidy was analysed using a flow cytometer MACS Quant (Miltenyi Biotec GmbH, Germany) equipped with an air-cooled laser $(488 \mathrm{~nm}$, fluorescence channel 4), and MACSQuantify ${ }^{\mathrm{TM}}$ software (Miltenyi Biotec $\mathrm{GmbH}$, Germany). In total, the fluorescence of at least 10,000 nuclei was analysed in each sample. Nuclei were gated on the basis of linear plots of PI fluorescence and side scatter area (PI-lin vs. SSC-A). Doublets were excluded using a forward height/forward area scatter plot (FSC-H vs. FSC-A). The control sample from $T$. pieninicum (the plant of known diploid DNA content) was used to set the diploid gate.

\section{Data analysis}

In each variant of storage 32 microshoots were used (16 shoot tips in each magenta). The experiments were conducted twice. Proliferation rate (an average shoots formed per explant) was obtained for shoots that survived the cold treatment for 3 and 9 months, while the rooting rate was calculated for 24 shoots. Data were expressed as mean \pm standard error (SE) and analysed by two-way ANOVA. Data concerning the amount of endogenous ABA were expressed as mean \pm standard deviation (SD). To examine significant differences among the treatments Tukey's multiple range test at $p<0.05$ was then performed.

\section{Results}

\section{Morphological analysis of stored material}

Shoot tips used in the experiment were the same size and healthy (Fig. 1a) and given a visual rating of 5 on establishment of culture, based on Reed's scale, decreasing with the duration of storage. The highest value was recorded for the cultures stored in dark on medium without ABA (Fig. 2). Light during storage on this medium decreased value of the visual rating of shoots. The addition of ABA to the medium also led to lower value of the parameter. After 9 months of storage the recorded visual rating decreased statistically significantly from 2.6 to 1.0 in the dark and from 1.2 to 0.6 at light condition (Fig. 2).

\section{Regrowth of stored shoots}

Shoots after 3 and 9 months of storage at $10{ }^{\circ} \mathrm{C}$ in dark and at light conditions on medium with or without $\mathrm{ABA}$ (Fig. 1b, c) were regrown under optimal conditions on medium supplemented with $1.1 \mu \mathrm{M}$ BAP and $0.14 \mu \mathrm{M}$ NAA. Number of shoots per explants recorded after regrowth (1st subculture) following 3 months of storage ranged from 8.9 to 13.6; the differences were not statistically significant and proliferation rates were comparable to results obtained during the propagation of the control material (Fig. 3a). After the second subculture proliferation rates were higher only for material storage on medium without ABA both in light and in the dark (15.5 and 12.6, 

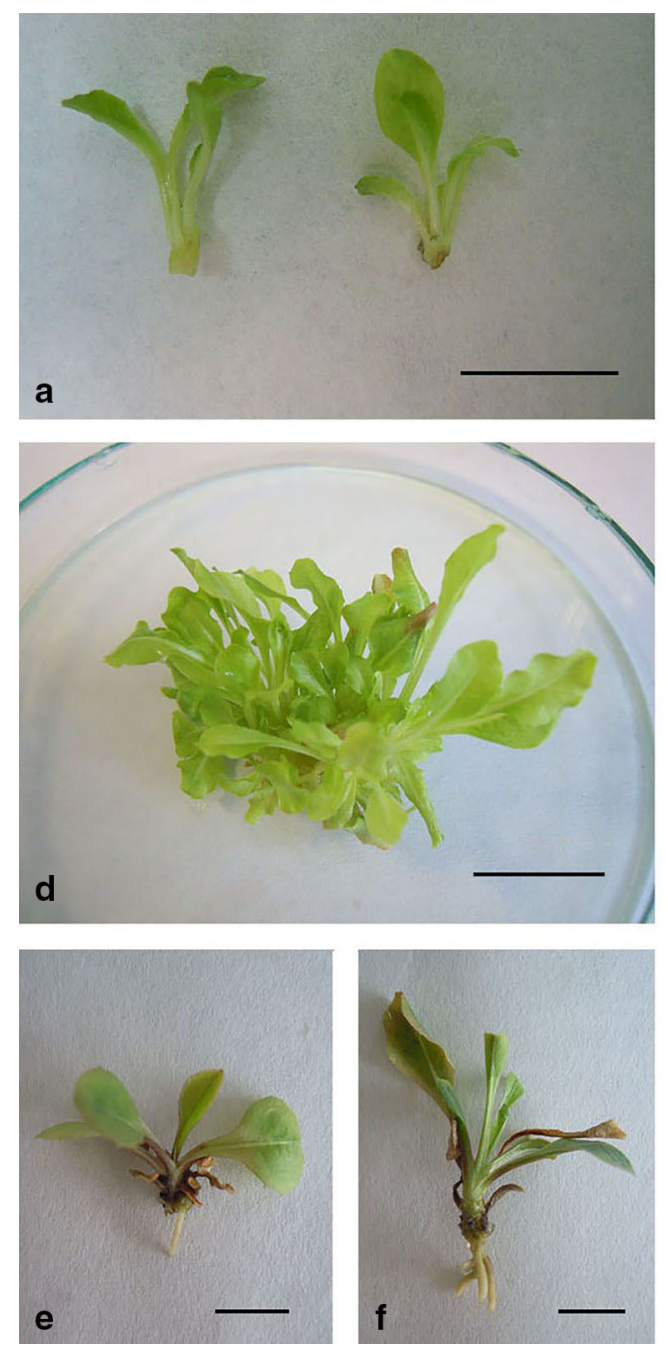

Fig. 1 In vitro storage of Taraxacum pieninicum: isolated shoots before storage (a), shoots after 9 months of treatment at $10{ }^{\circ} \mathrm{C}$ in darkness (b) and under light conditions (c), regrowth of shoots at $25{ }^{\circ} \mathrm{C}$ on medium with BA $1 \mathrm{mg} \mathrm{dm}^{-3}$ and NAA $0.1 \mathrm{mg} \mathrm{dm}^{-3}$ (d),

respectively) but the differences were not statistically significant in compare to result obtained for shoots without cold-storage (Fig. 3b). Extension of the storage to 9 months did not reduce significantly shoots proliferation and those were comparable to results obtained during the propagation of the material without low temperature storage (Figs. 1d, 3a, b). Reducing the shoots number per explant was recorded only during 1 st subculture of regrowth in the case of shoots stored on medium with $\mathrm{ABA}$ in dark. While the increase of the proliferation rate (20.6) was achieved for shoots stored on medium without ABA in light condition in 1st subculture, the difference were statistically significant in comparison to shoots cold-stored for 3 months and non-stored (Fig. 3a; Table 1). Also, in the second subculture of shoots stored for 9 months on medium without $\mathrm{ABA}$ the observed proliferation rates had the

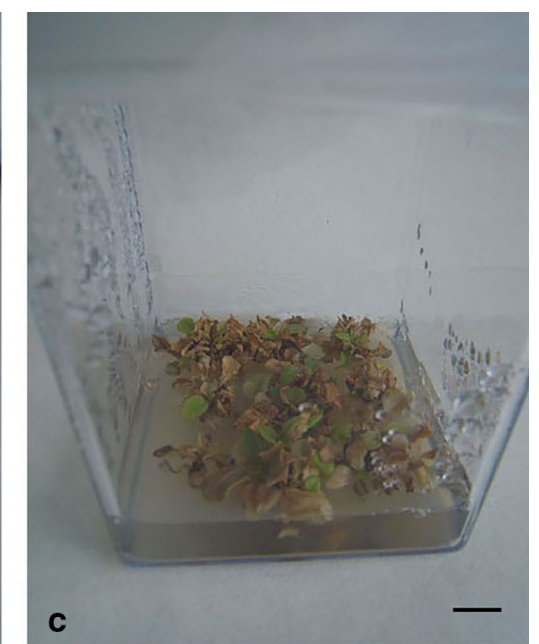
rooted shoots on medium without plant regulators after storage for
3 months in the dark (e) and 9 months under light conditions (f), flowered plants after adaptation to field conditions

highest value, and was 22.8 when storage was carried out in the dark and 20.4 in light conditions (Fig. 3b). After the second passage, it was found that the material stored for 9 months on medium without $\mathrm{ABA}$ regardless of the light conditions and on medium with $\mathrm{ABA}$ in the dark propagated better in comparison to shoots stored for 3 months, and the differences were statistically significant, but in relation to non-stored shoots differences were not statistically significant (Fig. 3b; Table 2).

\section{ABA level in stored plants}

The level of endogenous ABA in the tissue of T. pieninicum shoots after 3 months of storage in darkness was comparable to tissue not stored at low temperature. By contrast the storage in light conditions resulted in a 2.5 -fold 


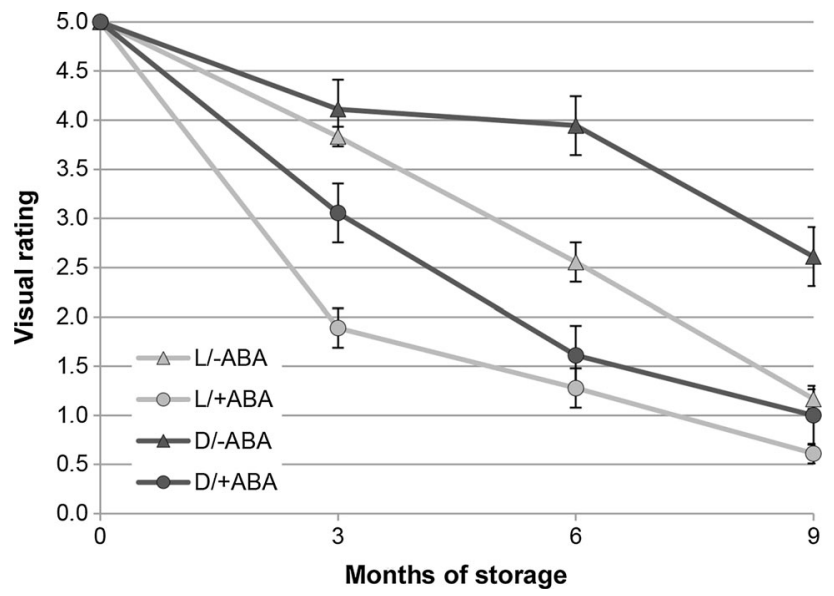

Fig. 2 The effect of ABA during storage at $10{ }^{\circ} \mathrm{C}$ in darkness (D) and under light conditions (L) on the visual rating of Taraxacum pieninicum shoots

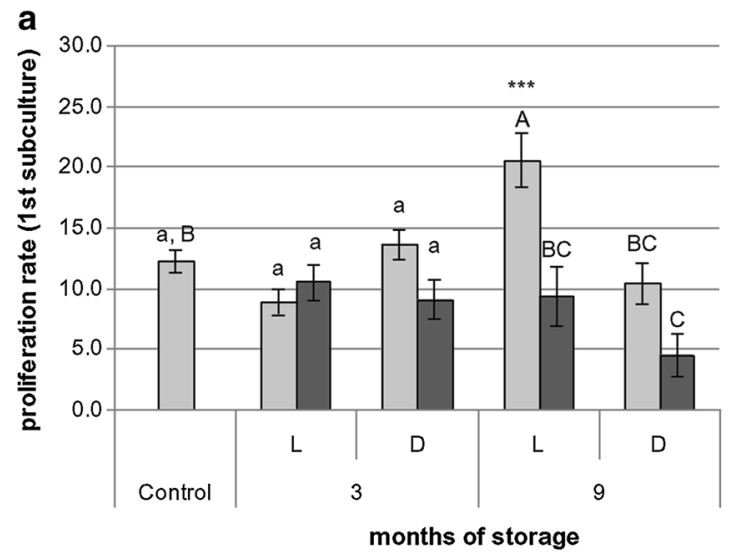

$\square(-) A B A$

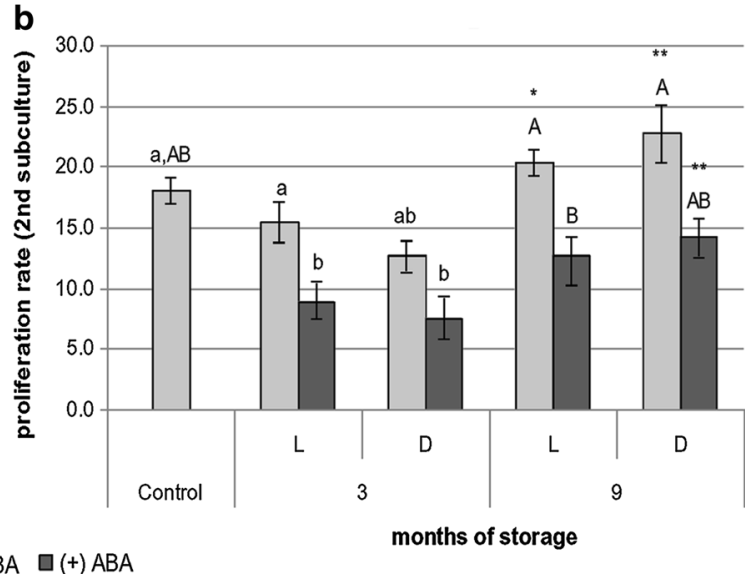

Fig. 3 The effect of $\mathrm{ABA}$ and the duration of storage at $10{ }^{\circ} \mathrm{C}$ in darkness (D) and light conditions (L) on the multiple rate of shoots during regrowth in the 1 st subculture (a), in the 2nd subculture (b) of Taraxacum pieninicum. Means in the same storage period with
Table 2 Analysis of the interaction of light conditions and ABA treatment during cold storage on the rooting of $T$. pieninicum after regrowth performed by two-way ANOVA

\begin{tabular}{lllll}
\hline Treatment & \multicolumn{3}{l}{ Rooting rate } & \\
\cline { 2 - 5 } & MS & \multicolumn{1}{l}{$F$} & $p$ value & \\
\hline 3 months of storage & & & & \\
Light conditions (A) & 2.08 & 3.50 & 0.0679 & ns \\
ABA (B) & 1.33 & 2.24 & 0.1414 & ns \\
A $\times$ B & 8.33 & 14.01 & 0.0005 & \\
9 months of storage & & & & \\
Light conditions (A) & 0.19 & 0.32 & 0.5767 & ns \\
ABA (B) & 0.19 & 0.32 & 0.5767 & $\mathrm{~ns}$ \\
A $\times$ B & 0.52 & 0.88 & 0.3537 & $\mathrm{~ns}$ \\
\hline
\end{tabular}

different letters are significantly different followed by Tukey's test at $p \leq 0.05$, significant differences between the same treatment in different storage periods at $* p<0.05, * * p<0.01, * * * p<0.001$

Table 1 Analysis of the interaction between the light conditions and ABA treatment during cold storage on the visual rating after storage and during multiplication of shoots of $T$. pieninicum performed by two-way ANOVA

\begin{tabular}{|c|c|c|c|c|c|c|c|c|c|c|c|}
\hline \multirow[t]{2}{*}{ Treatment } & \multicolumn{3}{|c|}{ Visual rating } & \multicolumn{4}{|c|}{ Multiple rate 1 st subculture } & \multicolumn{4}{|c|}{ Multiple rate 2 nd subculture } \\
\hline & MS & $F$ & $p$ value & MS & $F$ & $p$ value & & MS & $F$ & $p$ value & \\
\hline \multicolumn{12}{|l|}{3 months of storage } \\
\hline Light conditions (A) & 9.39 & 14.85 & 0.0003 & 48.35 & 1.49 & 0.2272 & ns & 76.24 & 1.64 & 0.2043 & ns \\
\hline $\mathrm{ABA}(\mathrm{B})$ & 40.50 & 64.05 & $<0.0001$ & 39.01 & 1.20 & 0.2775 & ns & 588.24 & 12.69 & 0.0007 & \\
\hline $\mathrm{A} \times \mathrm{B}$ & 3.56 & 5.62 & 0.0206 & 171.13 & 5.26 & 0.0250 & & 8.47 & 0.18 & 0.6704 & ns \\
\hline \multicolumn{12}{|l|}{9 months of storage } \\
\hline Light conditions (A) & 15.13 & 29.34 & $<0.0001$ & 1012.50 & 13.24 & 0.0005 & & 66.01 & 1.37 & 0.2463 & ns \\
\hline $\mathrm{ABA}(\mathrm{B})$ & 21.13 & 40.98 & $<0.0001$ & 1317.56 & 17.22 & $<0.0001$ & & 1096.02 & 22.73 & $<0.0001$ & \\
\hline $\mathrm{A} \times \mathrm{B}$ & 5.01 & 9.73 & 0.0027 & 128.00 & 1.67 & 0.2002 & $\mathrm{~ns}$ & 3.31 & 0.07 & 0.7942 & ns \\
\hline
\end{tabular}


increase in ABA level (Fig. 4). Extension of the storage to 9 months caused an increase in the level of ABA independent of the light conditions (Fig. 4).

Addition of ABA to storage-medium resulted in an eightfold increase in the level of ABA in shoots of $T$. pieninicum after 3 months and a tenfold increase after 9 months of storage in comparison to tissue storage on medium without ABA (Fig. 5).

\section{Rooting of the regrown shoots and acclimatization}

Shoots from the 2nd subculture of regrowth were isolated and transferred to rooting medium (MS without plant regulators). Rooting of shoots stored on medium without $\mathrm{ABA}$ in the dark and with $\mathrm{ABA}$ in light for 3 months was effective, shoots were able to produce root with an average 1.5 and 0.8 roots per shoot, respectively (Fig. 1e). Percentage of rooted shoots ( $75 \%$ and more) was comparable to the values obtained for non-stored plants. However, storage during 3 months on medium without $\mathrm{ABA}$ in light conditions and with $\mathrm{ABA}$ in dark inhibited rooting of shoots, the differences were statistically significant in comparison to shoots non cold-stored (Fig. 6), only $25 \%$ shoots were rooted. Extension of the storage to 9 months did not inhibit this process. In the case of shoots stored in light on medium without $\mathrm{ABA}$ and in dark on medium with ABA rooting was even more efficient than after 3 months stored, the differences were statistically significant

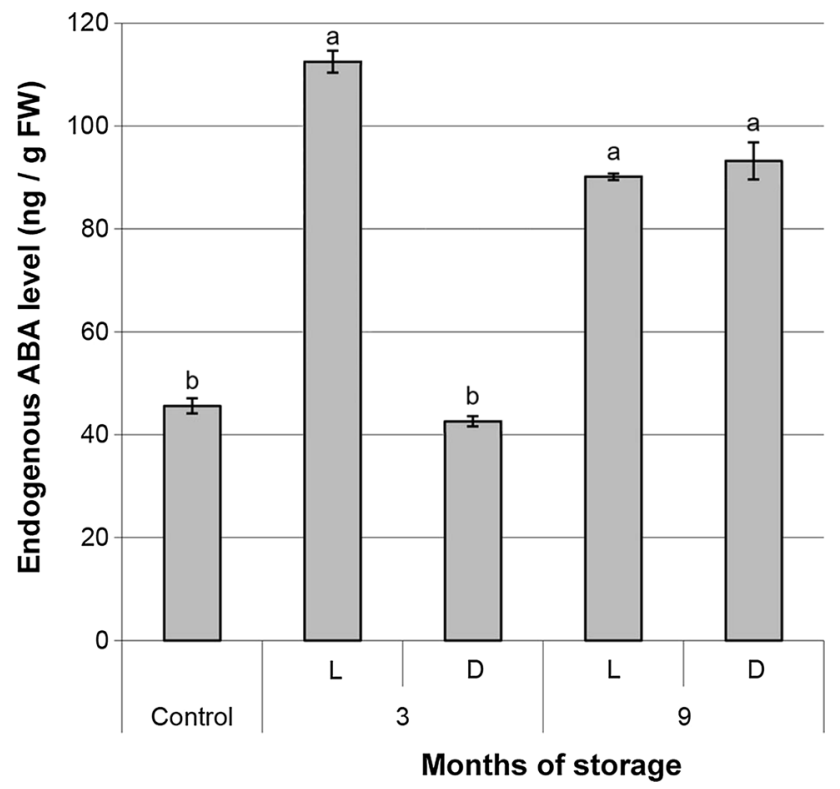

Fig. 4 Changes in ABA content [ng/g FW] in leaves of Taraxacum pieninicum shoots after in vitro storage at low temperature in darkness (D) or in light conditions (L). Control was leaves isolated from shoots not subjected to cooling. Means with different letters are significantly different followed by Tukey's test at $p \leq 0.05$

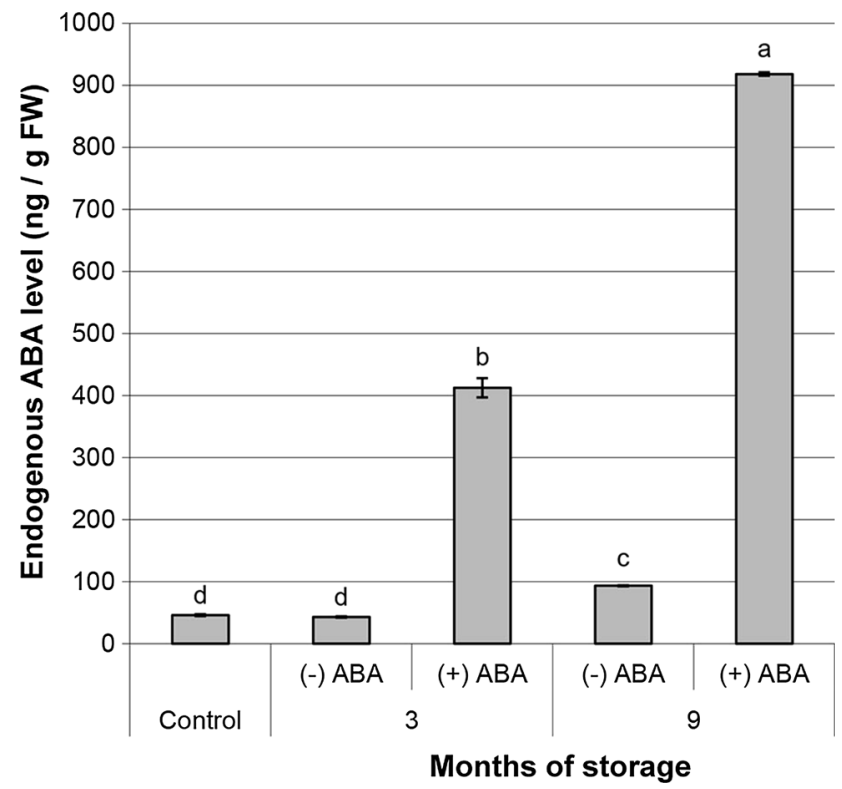

Fig. 5 The effect of $5 \mu \mathrm{M}$ ABA added to the storage medium on the level of endogenous ABA in leaves of Taraxacum pieninicum shoots during storage at $10{ }^{\circ} \mathrm{C}$ in darkness. Control was leaves isolated from shoots not subjected to cooling. Means with different letters are significantly different followed by Tukey's test at $p \leq 0.05$

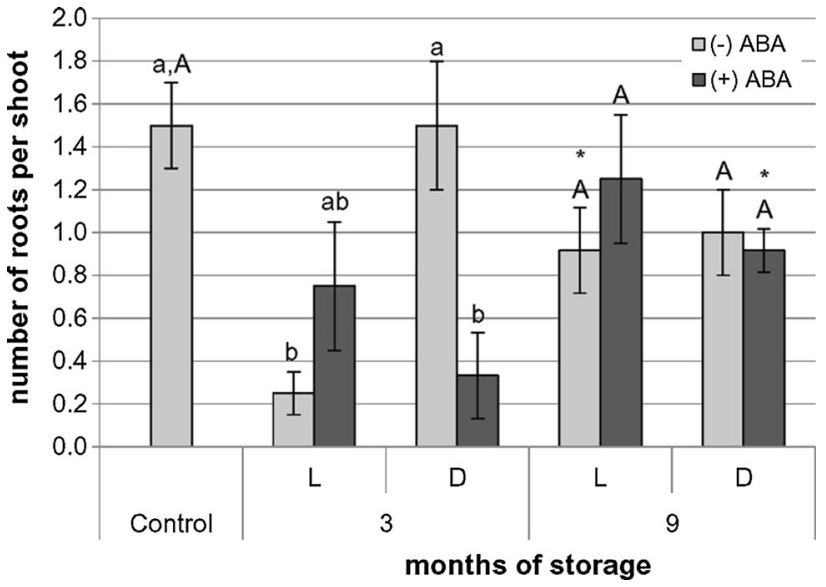

Fig. 6 The effect of $\mathrm{ABA}$ and the duration of storage at $10^{\circ} \mathrm{C}$ in darkness (D) and light conditions (L) on rooting of Taraxacum pieninicum shoots after regrowth. Means in the same storage period with different letters are significantly different followed by Tukey's test at $p \leq 0.05$

(Figs. 1f, 6). Addition of ABA to the medium during cold storage followed by dark conditions meaningfully reduced rooting of shoots, but this effect was observed only for shoots stored for 3 months; the differences were statistically significant. Microcuttings showed high survival during acclimatization and after 8 weeks of adaptation to soil conditions more than $90 \%$ of individuals have displayed growth. All plantlets flowered after adaptation to field conditions over 2 years (Fig. 1g). 


\section{DNA content of stored plants}

DNA content was measured by flow cytometry in plants stored for 9 months at low temperature. Data for plants obtained from shoots stored for 9 months are presented in Fig. 7. The flow cytometry results indicated that all the regenerants from material stored at low temperature and regrown on medium supplemented with $1.1 \mu \mathrm{M}$ BAP and $0.14 \mu \mathrm{M}$ NAA had the same ploidy level independently of the light condition and the presence of ABA in medium during storage.

\section{Discussion}

In this study we investigated optimal conditions for in vitro storage of $T$. pieninicum. Morphological analysis of shoots indicates that the light had a negative effect on the condition of the shoot during cold storage. However, these changes concerned leaves only, while meristems were not damaged. Similar results were obtained for the shoots of Pyrus genotypes where incubation at low temperature and light intensity resulted in yellowing of shoots, leaf size became very small but the shoot tips were quite fresh and green (Ahmed et al. 2010). In our previous studies on the storage of Senecio macrophyllus light also had a negative effect on shoots condition during storage, and addition of ABA to the medium improved their condition (Trejgell et al. 2015). Poplar shoots were in better condition after storage in the dark than under light (Hausman et al. 1994). Vigorous growth of Malus and Pistacia lentiscus after cooling was obtained also following dark storage (Orlikowska et al. 2010; Koç et al. 2014). The presence of $5 \mu \mathrm{M}$ ABA in the medium even more decreased condition of $T$. pienicum shoots. In the study of the cold response of Hypericum, it was found that the supplementation of exogenous ABA to preculture medium lowered the content of water in plant tissue. However, low concentration of ABA was not sufficient to induce the low-temperature tolerance (Bruňáková et al. 2011, 2015).

Proliferation rates were comparable to results obtained during the propagation of the material without storage at low temperature (Trejgell et al. 2013). Cold storage led to an increase in the proliferation rate in Alnus glutinosa, although the proliferation returned to normal levels in subsequent subcultures (San José et al. 2014). A similar effect was obtained after storage of Podophyllum peltatum where the proliferation rate after 4 and 8 months at a temperature of $10{ }^{\circ} \mathrm{C}$ was higher than at $25^{\circ} \mathrm{C}$ (Lata et al. 2010). Cold storage in the dark of apple cultures also caused an increase in adventitious shoot number (Orlikowska et al. 2010).

ABA is a well-known retardant used to increase the resistance to cold. However, in our study the presence of
ABA in the medium during storage of $T$. pieninicum shoots at low temperatures caused a reduction in the efficiency of the multiplication of shoots after storage. Only in the case of shoots from the 1st subculture transferred after 3 months of storage under light was there no difference in effectiveness between the shoots cultured on medium with or without ABA. This may be associated with a strong increase in the level of endogenous ABA during the first three months of storage recorded only in the shoots stored in light.

However, light conditions in combination with low temperature were a stronger stress-factor leading to an increase in the level of ABA than low temperature. In the case of woody plants (e.g. Betula pendula) low temperature in combination with short day increased endogenous ABA more than continuous light (Li et al. 2002). The amount of ABA also increased in Rosa $x$ hybrida during storage in darkness (Arve et al. 2013). A high level of ABA in stored shoots had a negative impact on both the visual rating (Fig. 2) and the rate of proliferation during regrowth (Fig. 3). Exposure of axillary buds on medium supplemented with ABA at $0.04-37.8 \mu \mathrm{M}$ for $1-3$ months also inhibited both axillary buds and root development of Ipomoea batatas. This effect was maintained up to 30 days after transfer on to medium without ABA. Rapid and normal plantlet development was observed in the following period (Jarret and Gawel 1991). Medium supplementation with 3.8-11.4 $\mu \mathrm{M}$ ABA resulted in a significant decrease in survival after cold storage of Vitis heyneana (Pan et al. 2014), Tetrastigma hemsleyanum (Peng et al. 2015) and negatively affected shoot growth of Piper aduncum and Piper hispidinervum (Silva and Scherwinski-Pereira 2011).

Endogenous ABA level might be controlled by light. ABA biosynthetic genes are highly expressed in far-red light (FR); in contrast an ABA deactivating gene is upregulated by red light $(\mathrm{R})$. Light signals are transmitted to ABA-metabolic genes via phytochrome (Xu et al. 2014; Seo et al. 2009). The results of the study by Reddy et al. (2013) showed that ABA regulated bud outgrowth responses to the red light/far-red light ratio (R:FR) in Arabidopsis thaliana. ABA levels were high in axillary buds under low R:FR and decreased by high R:FR, which promoted out-growth of buds. Increasing the R:FR ratio resulted in a conformational change of phytochrome that forms the Pfr state. We suppose that the same effect was in our study during the storage under continuous light and might be a cause of a lower rate of proliferation during regrowth of $T$. pieninicum.

As expected, content of endogenous ABA increased substantially in shoots stored on medium with ABA. Exogenous ABA was easily absorbed by plants and this pool could be add to endogenous ABA (Pospísilová et al. 2009). Furthermore it was higher in plants grown under 

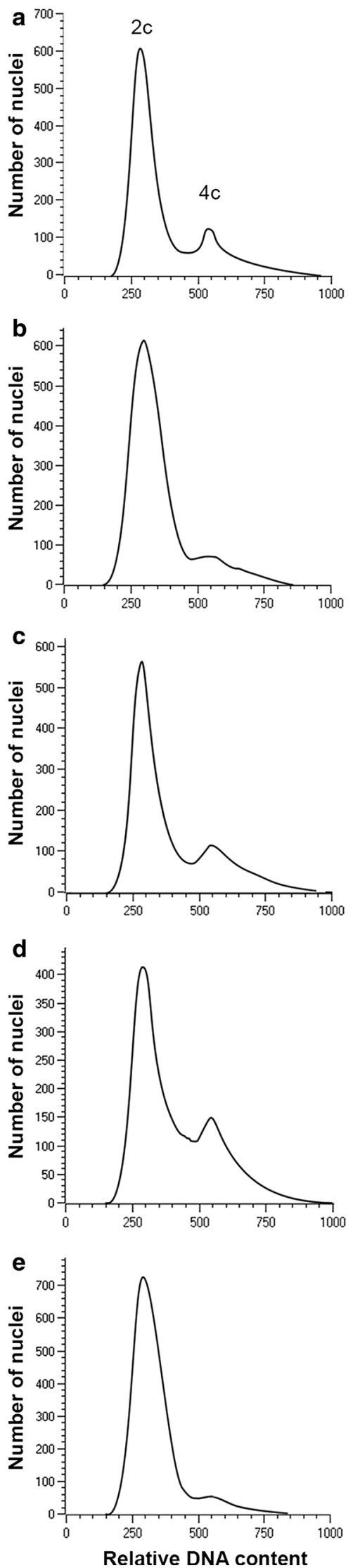

4ig. 7 Flow cytometry histograms of Taraxacum pieninicum after 9 months of in vitro storage at low temperature in magenta boxes: control plant (without storage at low temperature) (a), in light conditions on medium without $\mathrm{ABA}(\mathbf{b})$, in light conditions on medium with $\mathrm{ABA}(\mathbf{c})$, in darkness on medium without $\mathrm{ABA}(\mathbf{d})$, in darkness on medium with $\mathrm{ABA}(\mathbf{e})$

light conditions than in the dark. The increase in ABA content was also observed in Nicotiana tabacum plants grown ex vitro under high irradiance (Hofman et al. 2002; Hronková et al. 2003).

The application of ABA to plants mimics the effect of a stress condition. As many abiotic stresses ultimately result in cell desiccation and osmotic imbalance, there is an overlap in the expression pattern of stress genes after cold, drought or high salt. Several studies showed that phytochromes can affect ABA levels or signalling (Piskurewicz et al. 2009; Dubois et al. 2010). Moreover, González et al. (2012) suggest that phy B plays an important role in plant drought tolerance by enhancing sensitivity to $\mathrm{ABA}$ when water becomes limited.

Shoots of T. pieninicum after regrowth rooted on MS medium without auxin. Many species belonging to the family Asteraceae do not require supplementation of media by auxin (Koroch et al. 2002; Trejgell et al. 2010, 2012). Light inhibited rooting, but this effect was observed only in the case of shoots cold-stored for 3 months. During this period there was a significant increase in the concentration of endogenous ABA, which could have had an impact both on the process of multiplication (Fig. 3) and rooting (Fig. 6). It is known that ABA is essential in suppressing the formation of lateral roots (Wood 1983; Deak and Malamy 2005). However, exogenous ABA did not inhibit rooting when applied at physiological concentrations (Blake and Atkinson 1986).

It is well-known that in vitro culture approaches are occasionally associated with somaclonal variation. Changes in ploidy of cells depend on the concentration of growth regulators and the length of exposure to growth regulators. Such changes were observed during the regeneration of Gentiana kurroo with protoplasts isolated from cotyledons, where $30 \%$ of the plantlets presented a two or threefold DNA content compared to that of the control (Fiuk and Rybczyński 2007). Flow cytometry analysis of Carica papaya plantlets regenerated from immature zygotic embryos also evidenced a different DNA level (14\% of plants), which is often encountered in the regeneration via callus. However, during the multiplication stage from shoot tips of this species the DNA level remained stable (Clarindo et al. 2008). Plants propagated by induction of axillary buds from shoot tips have been comparatively genetically stable in comparison to plants obtained through adventitious regeneration methods (Ezura 
et al. 1997; Kanchanapoom et al. 2012; Adhikari et al. 2014). Similarly indirect somatic embryogenesis from leaf explants of Chrysanthemum morifolium (Naing et al. 2013) and Gentiana species (Fiuk and Rybczyński 2008), the plants showed the same ploidy level as donor plants. In our study all the regenerants from material stored at reduced temperature and regrown in optimal conditions had the same ploidy level, irrespective of the storage treatment.

\section{Conclusions}

The developed procedure for storage of $T$. pieninicum shoots at $10^{\circ} \mathrm{C}$ on medium without $\mathrm{ABA}$ allows the period between subculture to be extended to 9 months, regardless of light conditions. Proliferation rates obtained after poststorage regrowth were comparable to results obtained during the propagation of the material without storage at low temperature. The addition of ABA to storage medium resulted in an increase in endogenous ABA levels, which negatively affected the propagation of shoots during regrowth. Plantlets obtained after regrowth had the same ploidy level as control plants, independent of treatment during storage.

Acknowledgments This Project was supported by funds provided by Nicolaus Copernicus University (Torun, Poland) for the research programme of the Chair of Plant Physiology and Biotechnology.

Authors' contribution Monika Kamińska and Alina Trejgell designed and carried out the experiments, analysed the data and wrote the manuscript. Edyta Skrzypek carried out an analysis of the flow cytometer, Emilia Wilmowicz carried out an analysis of endogenous ABA content and Andrzej Tretyn helped in preparing the manuscript.

Open Access This article is distributed under the terms of the Creative Commons Attribution 4.0 International License (http://crea tivecommons.org/licenses/by/4.0/), which permits unrestricted use, distribution, and reproduction in any medium, provided you give appropriate credit to the original author(s) and the source, provide a link to the Creative Commons license, and indicate if changes were made.

\section{References}

Adhikari S, Bandyopadhyay TK, Ghosh P (2014) Assessment of genetic stability of Cucumis sativus L. regenerated from encapsulated shoot tips. Sci Hortic (Amsterdam) 170:115-122. doi:10.1016/j.scienta.2014.01.015

Ahmed M, Anjum MA, Shah AH, Hamid A (2010) In vitro preservation of Pyrus germplasm with minimal growth using different temperature regimes. Pak J Bot 42:1639-1650

Arve LE, Terfa MT, Gislerød HR, Olsen JE, Torre S (2013) High relative air humidity and continuous light reduce stomata functionality by affecting the ABA regulation in rose leaves. Plant Cell Environ 36:382-392. doi:10.1111/j.1365-3040.2012. 02580.x
Blake TJ, Atkinson SM (1986) The physiological role of abscisic acid in the rooting of poplar and aspen stump sprouts. Physiol Plant 67:638-643. doi:10.1111/j.1399-3054.1986.tb05070.x

Bruňáková K, Zámečník J, Urbanová M, Čellárová E (2011) Dehydration status of ABA-treated and cold-acclimated Hypericum perforatum L. shoot tips subjected to cryopreservation. Thermochim Acta 525:62-70

Bruňáková K, Petijová L, Zámečník J, Turečková V, Čellárová E (2015) The role of ABA in the freezing injury avoidance in two Hypericum species differing in frost tolerance and potential to synthesize hypericins. Plant Cell Tissue Organ Cult 122:45-56. doi:10.1007/s11240-015-0748-9

Clarindo WR, Carvalho CR, Araújo FS, Abreu IS, Otoni WC (2008) Recovering polyploid papaya in vitro regenerants as screened by flow cytometry. Plant Cell Tissue Organ Cult 92:207-214. doi:10.1007/s11240-007-9325-1

Cruz-Cruz CA, González-Arnao MT, Engelmann F (2013) Biotechnology and conservation of plant biodiversity. Resources 2:73-95. doi:10.3390/resources2020073

Deak KI, Malamy J (2005) Osmotic regulation of root system architecture. Plant J 43:17-28. doi:10.1111/j.1365-313X.2005. 02425.x

Dubois PG, Olsefski GT, Flint-Garcia S, Setter TL, Hoekenga OA, Brutnell TP (2010) Physiological and genetic characterization of end-of-day far-red light response in maize seedlings. Plant Physiol 154:173-186. doi:10.1104/pp.110.159830

Engelmann F (2011) Use of biotechnologies for the conservation of plant biodiversity. In Vitro Cell Dev Biol Plant 47:5-16. doi:10. 1007/s11627-010-9327-2

Espindula MC, Rocha VS, Grossi JAS, Souza MA, Souza LT, Favarato LF (2009) Use of growth retardants in wheat. Planta Daninha 27:379-387

Ezura H, Kikita I, Oosawa K (1997) Long-term ploidy stability of shoot primordium cultures and produced plants of melon. Plant Cell Tissue Organ Cult 48:31-35. doi:10.1023/A: 1005854523278

Fiuk A, Rybczyński JJ (2007) The effect of several factors on somatic embryogenesis and plant regeneration in protoplast cultures of Gentiana kurroo (Royle). Plant Cell Tissue Organ Cult 91:263-271. doi:10.1007/s11240-007-9293-5

Fiuk A, Rybczyński JJ (2008) Genotype and plant growth regulatordependent response of somatic embryogenesis from Gentiana spp. leaf explants. In Vitro Cell Dev Biol Plant 44:90-99. doi:10. 1007/s11627-008-9124-3

Galbraith DW, Harkins KR, Maddox JM, Ayres NM, Sharma DP, Firoozabady E (1983) Rapid flow cytometric analysis of the cell cycle in intact plant tissues. Science 220:1049-1051. doi:10. 1126/science.220.4601.1049

González CV, Ibarra SE, Piccoli PN, Botto JF, Boccalandro HE (2012) Phytochrome B increases drought tolerance by enhancing ABA sensitivity in Arabidopsis thaliana. Plant Cell Environ 35:1958-1968. doi:10.1111/j.1365-3040.2012.02529.x

Gopal J, Chamail A, Sarkar D (2002) Slow-growth in vitro conservation of potato germplasm at normal propagation temperature. Potato Res 45:203-213. doi:10.1007/BF02736115

Hausman JF, Neys O, Kevers C, Gaspar T (1994) Effect of in vitro storage at $4 \& \# \times B 0 ; C$ on survival and proliferation of poplar shoots. Plant Cell Tissue Organ Cult 38:65-67. doi:10.1007/ BF00034446

Hofman P, Haisel D, Komenda J, Vágner M, Tichá I, Schäfer C, Čapková V (2002) Impact of in vitro cultivation conditions on stress responses and on changes in thylakoid membrane proteins and pigments of tobacco during ex vitro acclimation. Biol Plant 45:189-195. doi:10.1023/A:1015180219628

Hronková M, Zahradníčková H, Šimková M, Šimek P, Heydová A (2003) The role of abscisic acid in acclimation of plants 
cultivated in vitro to ex vitro conditions. Biol Plant 46:535-541. doi:10.1023/A:1024811527499

Jarret RL, Gawel N (1991) Abscisic acid-induced growth inhibition of sweet potato (Ipomoea batatas L.) in vitro. Plant Cell Tissue Organ Cult 24:13-18. doi:10.1007/BF00044259

Kanchanapoom K, Chunui P, Kanchanapoom K (2012) Micropropagation of Anubias barteri var. Nana from shoot tip culture and the analysis of ploidy stability. Not Bot Horti Agrobot 40:148-151. doi:10.15835/nbha4027520

Koç İ, Onay A, Özden-Çiftçi Y (2014) In vitro regeneration and conservation of the lentisk (Pistacia lentiscus L.). Turk J Biol 38:653-663. doi:10.3906/biy-1401-69

Koroch A, Juliani HR, Kapteyn J, Simon JE (2002) In vitro regeneration of Echinacea purpurea from leaf explants. Plant Cell Tissue Organ Cult 69:79-83. doi:10.1023/A:1015042032091

Lata H, Moraes RM, Bertoni B, Pereira AMS (2010) In vitro germplasm conservation of Podophyllum peltatum L. under slow growth conditions. In Vitro Cell Dev Biol Plant 46:22-27. doi:10.1007/s11627-009-9243-5

Li C, Puhakainen T, Welling A, Viherä-Aarnio A, Ernstsen A, Junttila O, Heino P, Palva ET (2002) Cold acclimation in silver birch (Betula pendula). Development of freezing tolerance in different tissues and climatic ecotypes. Physiol Plant 116:478-488. doi:10.1034/j.1399-3054.2002.1160406.x

Murashige T, Skoog F (1962) A revised medium for rapid growth and bioassays with tobacco tissue cultures. Physiol Plant 15:437-497. doi:10.1111/j.1399-3054.1962.tb08052.x

Naing AH, Min JS, Park KI, Chung MY, Lim SH, Lim KB, Kim CK (2013) Primary and secondary somatic embryogenesis in Chrysanthemum (Chrysanthemum morifolium) cv. 'Baeksun' and assessment of ploidy stability of somatic embryogenesis process by flow cytometry. Acta Physiol Plant 35:2965-2974. doi:10.1007/s11738-013-1328-4

Orlikowska T, Zawadzka M, Kucharska D, Lahuta LB (2010) The influence of the cooling of donor cultures on the in vitro adventitious regeneration and carbohydrate metabolism of four dwarfing apple rootstocks. Acta Physiol Plant 32:333-340. doi:10.1007/s11738-009-0411-3

Pan XJ, Zhang WE, Li X (2014) In vitro conservation of native Chinese wild grape (Vitis heyneana Roem. \& Schult) by slow growth culture. Vitis 53:207-214

Paunescu A (2009) Biotechnology for endangered plant conservation: a critical overview. Rom Biotech Lett 14:4095-4103

Peng X, Ji Q, Wu H, Li Y (2015) Slow-growth conservation and clonal fidelity of Tetrastigma hemsleyanum microplants. In Vitro Cell Dev Biol Plant 51:463-470. doi:10.1007/s11627-015-97096

Piskurewicz U, Turecková V, Lacombe E, Lopez-Molina L (2009) Far-red light inhibits germination through DELLA-dependent stimulation of $\mathrm{ABA}$ synthesis and $\mathrm{ABI} 3$ activity. EMBO J 28:2259-2271. doi:10.1038/emboj.2009.170

Pospísiilová J, Synková H, Haisel D, Bat'ková P (2009) Effect of abscisic acid on photosynthetic parameters during ex vitro transfer of micropropagated tobacco plantlets. Biol Plant 53:11-20. doi:10.1007/s10535-009-0003-5

Reddy SK, Holalu SV, Casal JJ, Finlayson SA (2013) Abscisic acid regulates axillary bud outgrowth responses to the ratio of red to far-red light. Plant Physiol 163:1047-1058. doi:10.1104/pp.113. 221895

Reed BM (1992) Cold storage of strawberries in vitro: a comparison of three storage systems. Fruit Var J 46:98-102

San José MC, Valladares S, Janeiro LV, Corredoira E (2014) Cryopreservation of in vitro-grown shoot tips of Alnus glutinosa (L.) Gaertn. Acta Physiol Plant 36:109-116. doi:10.1007/ s11738-013-1391-x

Seo M, Nambara E, Choi G, Yamaguchi S (2009) Interaction of light and hormone signals in germinating seeds. Plant Mol Biol 69:463-472. doi:10.1007/s11103-008-9429-y

Silva TL, Scherwinski-Pereira JE (2011) In vitro conservation of Piper aduncum and Piper hispidinervum under slow-growth conditions. Pesq Agropec Bras (Brasília) 46:384-389. doi:10. 1590/S0100-204X2011000400007

Trejgell A, Michalska M, Tretyn A (2010) Micropropagation of Senecio macrophyllus M. Bieb. Acta Biol Cracov Ser Bot 52:67-72. doi:10.2478/v10182-010-0009-5

Trejgell A, Dąbrowska A, Tretyn A (2012) Micropropagation and influence of in vitro culture on development of Cirsium pannonicum (L. f.) link regenerants. Acta Sci Pol Hortorum Cultus 11:81-90

Trejgell A, Chernetskyy M, Podlasiak J, Tretyn A (2013) An efficient system for regenerating Taraxacum pieninicum Pawł. from seedling explants. Acta Biol Cracov Ser Bot 55:73-79. doi:10. 2478/abcsb-2013-00013

Trejgell A, Kamińska M, Tretyn A (2015) In vitro slow growth storage of Senecio macrophyllus shoots. Acta Physiol Plant 37:234. doi:10.1007/s11738-015-1983-8

Vine JH, Noiton D, Plummer JA, Baleriola-Lucas C, Mullins MG (1987) Simultaneous quantitation of indole 3-acetic acid and abscisic acid in small samples of plant tissue by gas chromatography/mass spectrometry/selected ion monitoring. Plant Physiol 85:419-422. doi: 10.1104/pp83.2.419

Wood BW (1983) Changes in indolacetic acid, abscisic acid, gibberellins and cytokinins during bud break in pecan. J Am Soc Hortic Sci 108:333-338

Wróbel I, Zarzycki K (2008) Taraxacum pieninicum Pawł. In: Mirek Z, Piękoś-Mirkowa $\mathrm{H}$ (eds) The red book of the polish carpathians, vascular plants institute of botany. W. Szafer Institute of Botany of the Polish Academy of Sciences Institute of Nature Conservation, Cracow, pp 406-408

Xu D, Li J, Gangappa SN, Hettiarachchi C, Lin F, Andersson MX, Jiang Y, Deng XW, Holm M (2014) Convergence of light and ABA signaling on the ABI5 promoter. PLoS Genet 10:e1004197. doi:10.1371/journal.pgen.1004197

Zarzycki K, Szeląg Z (2006) Red list of the vascular plants in Poland. In: Mirek Z (ed) Red list of plants and fungi in Poland. W. Szafer Institute of Botany Polish Academy of Sciences, Cracow, pp 9-20 